\title{
STUDIES ON REINFORCED HOLLOW CONCRETE BLOCK MASONRY
}

\author{
Madan Kumar L ${ }^{1}$, S. Raghunath ${ }^{2}$ \\ ${ }^{1}$ Assistant Professor, Department of Civil Engineering, JIT Davangere, Karnataka, India \\ ${ }^{2}$ Professor, Department of Civil Engineering, B.M.S.C.E Bengaluru-19, Karnataka, India
}

\begin{abstract}
Masonry may be defined as the assemblage of building units joined with the help of cementitious material or any accepted joining material to perform required function. It has its own reputation and performs multi-functions in load bearing structures such assupporting loads, dividing spaces, thermal and acoustic insulation, weather and fire protection etc, but it has to be provided separately in framed structures. In present scenario, there is a great demand for construction of Multi-storied residential buildings in urban area because of needful requirements. Most of such buildings are constructed using RC-framed structure. On the other hand RC-framed structures are expensive and relatively difficult to construct because of the need for formwork. Masonry has a great benefit since it does not need form work. If moderate to High strength Engineered hollow concrete blocks are available, one can think of providing reinforcement through the core of such Hollow blocks. In this project an attempt has been made to obtain the load carrying capacity of Reinforced Hollow Concrete Block Masonry through experimental investigation by considering two different percentages of steels - for this totally four number of Reinforced hollow concrete block masonry prisms (RHCBM) using $12 \mathrm{~mm}$ diameter bar and six number of Reinforced hollow concrete block masonry prisms (RHCBM) using $8 \mathrm{~mm}$ diameter bar were casted and tested. Further, an attempt has been made to compare the experimental load carrying capacity with the conventional mechanics based approach used for analyzing short columns. There was a fairly good corelation between the analysis and experiments.
\end{abstract}

Key Words: Unreinforced Masonry, Reinforced Hollow Concrete Block Masonry. $* * *$

\section{INTRODUCTION}

Masonry may be defined as the assemblage of building units joined with the help of cementitious material or any accepted joining material to perform required function. Based on structural perspective masonry can be classified into two types- Plain masonry and Reinforced masonry.

Plain masonry is one where the building units are bonded (or joined) with the help of cementitious material or any accepted joining material without any reinforcements. And, this type of masonry gives little tensile strength- hence it cannot be used in horizontal spanning members like beams, slabs and also for column where it is subjected tensile stresses due to eccentric loading. Similarly, reinforced masonry is type masonry where reinforcements are used in addition to plain masonry to improve its strength in both tension and compression.

\section{METHODOLOGY}

The Methodology adopted is conventional tests on a. Unreinforced HCB b. Reinforced Hollow Concrete Block Masonry. Two different percentages of reinforcement were tried prior to experiments on RHCBM, all the basic properties of Hollow concrete block, Mortar and Concrete was evaluated.

\section{EXPERIMENTAL INVESTIGATION}

In present investigation the prism specimens and masonry triplets were casted using hollow concrete block of dimension $400 \times 150 \times 200 \mathrm{~mm}$ for Compressive test and Shear test respectively. Fe-415 steel of diameter $12 \mathrm{~mm}$ and $8 \mathrm{~mm}$ were taken for reinforcement in RHCBM and 53 grade of ordinary Portland cement was used in all cases. The cement mortar 1:4 with w/c ratio 0.7 (obtained by Flow table test) was adopted. M20 grade concrete has been used for filling the cells of block in RHCBM. Totally four number of Reinforced hollow concrete block masonry prisms (RHCBM) using $12 \mathrm{~mm}$ diameter bar, six number of RHCBM using $8 \mathrm{~mm}$ diameter bar and three number of unreinforced masonry prisms were casted for Compression test. Similarly, three number of masonry triplets in two sets were casted and tested for two different normal stresses to evaluate the behavior of Shear Strength.

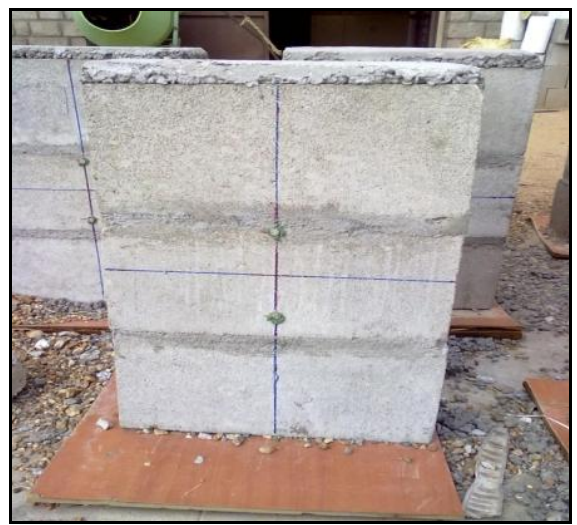

Fig -1: Prism Specimen after casting 


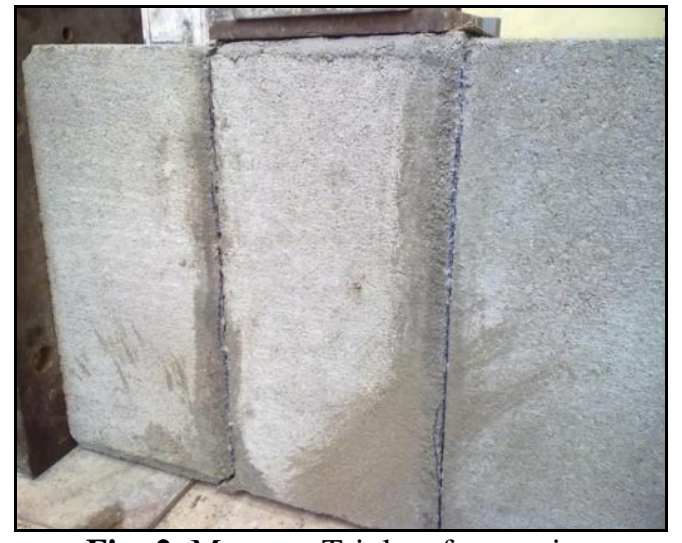

Fig -2: Masonry Triplet after casting

Table -1: Basic Properties of Hollow Concrete Block

\begin{tabular}{|l|l|l|l|}
\hline $\begin{array}{l}\text { Sl. } \\
\text { No }\end{array}$ & Name of the Test & Test Results & Unit \\
\hline 1 & Dimensionality & $\begin{array}{l}401.63 \times 152.07 \times 199 . \\
3\end{array}$ & $\mathrm{~mm}$ \\
\hline 2 & Dry density & 1.163 & $\mathrm{~g} / \mathrm{cc}$ \\
\hline 3 & Water absorption & 5.33 & $\%$ \\
\hline 4 & $\begin{array}{l}\text { Initial rate of } \\
\text { absorption }\end{array}$ & 1.25 & $\begin{array}{l}\mathrm{kg} / \mathrm{m}^{2} \\
/ \mathrm{min}^{2}\end{array}$ \\
\hline 5 & $\begin{array}{l}\text { Flexural strength } \\
\mathrm{N} / \mathrm{m} \\
\mathrm{m}^{2}\end{array}$ \\
\hline 6 & $\begin{array}{l}\text { Compressive } \\
\text { strength }\end{array}$ & 6.08 & $\begin{array}{l}\mathrm{N} / \mathrm{m} \\
\mathrm{m}\end{array}$ \\
\hline 7 & $\begin{array}{l}\text { Modulus } \\
\text { Elasticity }\end{array}$ & 5898 & $\mathrm{MPa}$ \\
\hline
\end{tabular}

Table -2: Basic Properties of Cement Mortar

\begin{tabular}{|l|l|l|l|}
\hline Sl.No & $\begin{array}{l}\text { Name of the } \\
\text { Test }\end{array}$ & Test Results & Unit \\
\hline 1 & $\begin{array}{l}\text { Compressive } \\
\text { strength }\end{array}$ & 12.92 & $\mathrm{~N} / \mathrm{mm}^{2}$ \\
\hline 2 & Flowability & 0.7 & - \\
\hline
\end{tabular}

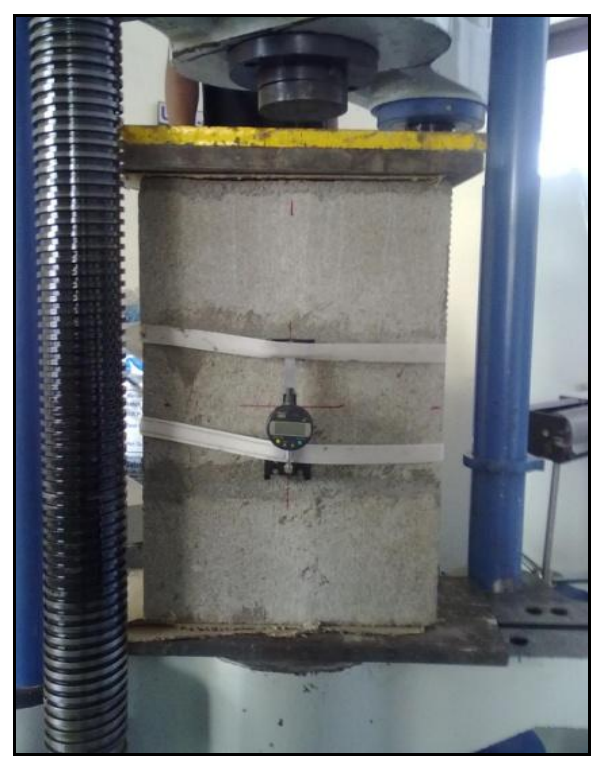

Fig -3: Setup for Compression test

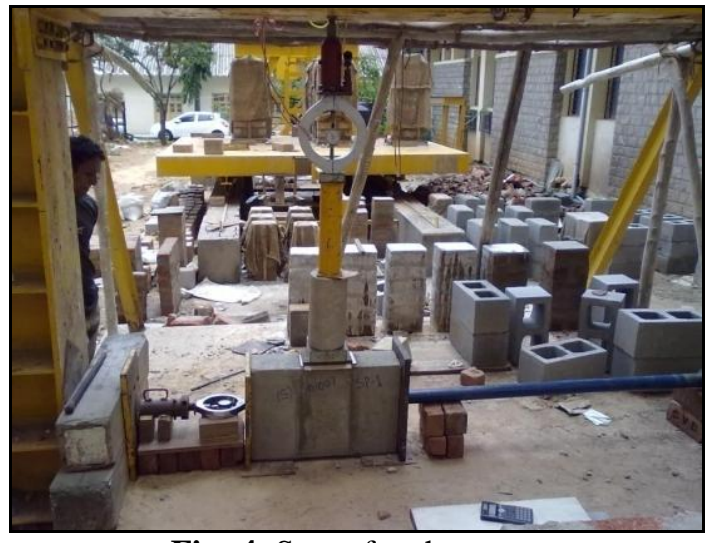

Fig -4: Setup for shear test

Table -3: Compressive strength of URM at 28 days

\begin{tabular}{|l|l|l|l|l|}
\hline $\begin{array}{l}\text { S1 } \\
\text { o }\end{array}$ & $\begin{array}{l}\text { Compressi } \\
\text { ve Strength } \\
\text { in Mpa }\end{array}$ & $\begin{array}{l}\text { Correctio } \\
\text { n Factor }\end{array}$ & $\begin{array}{l}\text { Corrected } \\
\text { Compressi } \\
\text { ve strength } \\
\text { in MPa }\end{array}$ & $\begin{array}{l}\text { Average } \\
\text { Compressi } \\
\text { ve Strength } \\
\text { in Mpa }\end{array}$ \\
\hline 1 & 3.73 & 1.31 & 4.88 & \multirow{2}{*}{6.83} \\
\cline { 1 - 2 } 2 & 6.22 & 1.31 & 8.15 & \\
\hline 3 & 5.7 & 1.31 & 7.47 & \\
\hline
\end{tabular}

Table -4: Compressive strength of RHCBM-12ф at 28 days

\begin{tabular}{|l|l|l|l|l|}
\hline $\begin{array}{l}\text { S1 } \\
\text { o }\end{array}$ & $\begin{array}{l}\text { Compressi } \\
\text { ve Strength } \\
\text { in Mpa }\end{array}$ & $\begin{array}{l}\text { Correctio } \\
\text { n Factor }\end{array}$ & $\begin{array}{l}\text { Corrected } \\
\text { Compressi } \\
\text { ve strength } \\
\text { in MPa }\end{array}$ & $\begin{array}{l}\text { Average } \\
\text { Compressi } \\
\text { ve Strength } \\
\text { in Mpa }\end{array}$ \\
\hline 1 & 7.23 & 1.31 & 9.48 & \multirow{2}{*}{11.1} \\
\cline { 1 - 4 } 2 & 7.75 & 1.31 & 10.16 & \\
\cline { 1 - 4 } 3 & 9.5 & 1.31 & 12.46 & \\
\cline { 1 - 3 } 4 & 9.37 & 1.31 & 12.28 & \\
\hline
\end{tabular}

Table -5: Compressive strength of RHCBM-8ф at 28 days

\begin{tabular}{|c|c|c|c|c|}
\hline $\begin{array}{l}\mathrm{Sl} \\
\mathrm{N} \\
\mathrm{O}\end{array}$ & $\begin{array}{l}\text { Compressi } \\
\text { ve Strength } \\
\text { in Mpa }\end{array}$ & $\begin{array}{l}\text { Correctio } \\
\text { n Factor }\end{array}$ & $\begin{array}{l}\text { Corrected } \\
\text { Compressi } \\
\text { ve strength } \\
\text { in } \mathrm{MPa}\end{array}$ & $\begin{array}{l}\text { Average } \\
\text { Compressi } \\
\text { ve Strength } \\
\text { in Mpa }\end{array}$ \\
\hline 1 & 6.1 & 1.31 & 8 & \multirow{6}{*}{9.09} \\
\hline 2 & 5.2 & 1.31 & 6.82 & \\
\hline 3 & 8.02 & 1.31 & 10.51 & \\
\hline 4 & 6.73 & 1.31 & 8.83 & \\
\hline 5 & 7.33 & 1.31 & 9.62 & \\
\hline 6 & 8.2 & 1.31 & 10.75 & \\
\hline
\end{tabular}


Table -6: Shear Strength of Masonry Triplets at 28 days

\begin{tabular}{|c|c|c|c|}
\hline S1 No & $\begin{array}{l}\text { Normal Stress } \\
\left(\mathrm{N} / \mathrm{mm}^{2}\right)\end{array}$ & $\begin{array}{l}\text { Shear } \\
\text { strength } \\
\left(\mathrm{N} / \mathrm{mm}^{2}\right)\end{array}$ & $\begin{array}{l}\text { Average } \\
\text { Shear } \\
\text { Strength } \\
\left(\mathrm{N} / \mathrm{mm}^{2}\right)\end{array}$ \\
\hline 1 & 0.007 & 0.168 & \multirow{3}{*}{0.191} \\
\hline 2 & 0.007 & 0.199 & \\
\hline 3 & 0.007 & 0.207 & \\
\hline 4 & 0.01 & 0.184 & \multirow{3}{*}{0.219} \\
\hline 5 & 0.01 & 0.253 & \\
\hline 6 & 0.01 & 0.222 & \\
\hline
\end{tabular}

Also, an attempt has been made to calculate the load carrying capacity of RHCBM using the mechanics based approach and the details are mentioned below.

Table -7: Axial load capacity of RHCBM (Experimental and Analytical)

\begin{tabular}{|c|c|c|c|c|}
\hline Steel & $\begin{array}{l}\text { Experimental } \\
\text { Load, } \\
(\mathrm{kN})\end{array}$ & $\mathrm{P}_{\mathrm{o}}$ & $\begin{array}{l}\text { Analytical } \\
\text { Load, } \quad \mathrm{P}_{\mathrm{o}} \\
(\mathrm{kN})\end{array}$ & $\begin{array}{l}\% \\
\text { Difference }\end{array}$ \\
\hline URM & $\begin{array}{l}312.83 \\
\text { (avg. of } \\
\text { specimen) }\end{array}$ & 3 & 364.8 & 16.61 \\
\hline $\begin{array}{l}4 \times 8 \\
\phi\end{array}$ & $\begin{array}{l}415.83 \\
\text { (avg. of } \\
\text { specimen) }\end{array}$ & 6 & 429.44 & 3.27 \\
\hline $\begin{array}{l}4 \times 12 \\
\phi\end{array}$ & $\begin{array}{l}507.75 \\
\text { (avg. of } \\
\text { specimen) }\end{array}$ & 3 & 477.19 & 6.01 \\
\hline
\end{tabular}

Further, the shear strength of hollow concrete block masonry triplets compared with Ready-made mortar. The table given below gives the summary of the comparison of the shear strength v/s normal stress.

Table -8: Comparison of Shear Strength

\begin{tabular}{|c|c|c|}
\hline $\begin{array}{l}\text { Normal } \\
\text { Stress } \\
\text { Applied } \\
\text { (Mpa) }\end{array}$ & $\begin{array}{l}\text { Shear Strength of } \\
\text { HCB Masonry } \\
\text { Triplets using } \\
\text { Conventional } \\
\text { Mortar (1:4) }\end{array}$ & $\begin{array}{l}\text { Shear Strength of HCB } \\
\text { Masonry Triplets using } \\
\text { Ready-Made Mortar }\end{array}$ \\
\hline 0.007 & 0.191 & 0.37 \\
\hline 0.01 & 0.219 & 0.54 \\
\hline
\end{tabular}

\section{SHEAR STRENGTH V/S NORMAL STRESS}

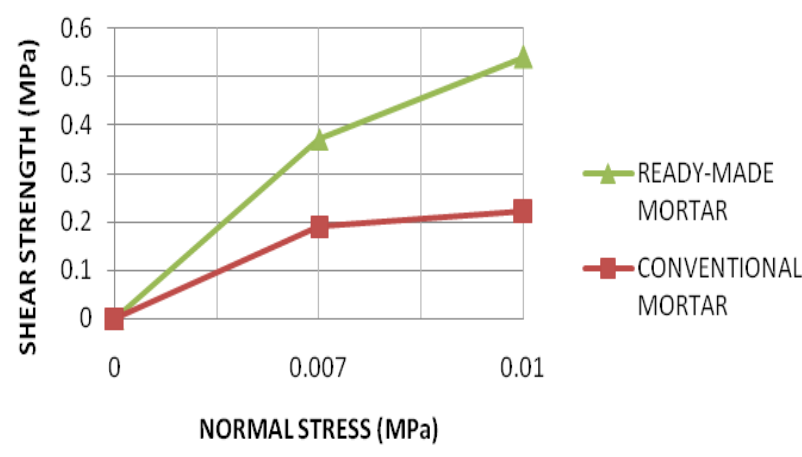

Chart -1: Comparison of Shear Strength v/s Normal Stress

\section{CONCLUSIONS}

The present investigation focused on the axial load carrying capacity of RHCBM based on the experimental and analytical investigation the following broad set of conclusions may be drawn:

[1]. Water absorption of HCB if found to be $5.33 \%$.

[2]. The Block Density of HCB is found to be $1.163 \mathrm{~g} / \mathrm{cc}$.

[3]. IRA for HCB is found to be $1.25 \mathrm{~kg} / \mathrm{m}^{2} / \mathrm{min}$.

[4]. The average Flexural Strength of HCB is 1.92 $\mathrm{N} / \mathrm{mm}^{2}$. This is indeed very high compared to conventional masonry units, because these HCB's are manufacture for a design mix under good quality control

[5]. The average compressive strength and modulus of elasticity of HCB blocks is found to be $6.08 \mathrm{~N} / \mathrm{mm}^{2}$ and $5898 \mathrm{Mpa}$.

[6]. The average Compressive Strength of Mortar Cube (1:4) with a w/c ratio of 0.7 is found to be $6.57 \mathrm{Mpa}$ and $\quad 12.92 \mathrm{Mpa}$ for 7 and 28 days respectively.

[7]. The average Compressive Strength and modulus of elasticity of URM is found to be $6.83 \mathrm{Mpa}$ and $17265 \mathrm{MPa}$ respectively with the masonry efficiency of $112.39 \%$. There is a need to explore this further since for such HCB with M1 grade mortar, efficiency is generally less than $100 \%$.

[8]. The average Compressive Strength and modulus of elasticity of RHCBM-12ф (reinforced using $12 \mathrm{~mm}$ bar) is found to be $11.1 \mathrm{MPa}$ and $22072 \mathrm{MPa}$ with the masonry efficiency of $182.5 \%$.

[9]. The average Compressive Strength of RHCBM-8 $\phi$ (reinforced using $8 \mathrm{~mm}$ bar) is found to be 9.09 MPa.

[10]. The simple mechanics based approach gives a very good co-relation for theoretically calculated ultimate load and experimental ultimate load.

\section{REFERENCES}

[1]. Beer Johnston De Wolf, "Mechanics of Materials", 2004, Mc-Graw-Hill New York.

[2]. Jagadish.K.S, Venkataraman Reddy B.V, Nanjunda Rao K.S (2009), “Alternative Building Materials and Technologies" New Age International Publishers, 


\section{Bangalore}

[3]. Narendra taly (2007), "Design of Reinforced Masonry Structures” Mc-Graw-Hill Publicatin, New York

[4]. IS: 456-2000 "Code of Practice for structural plain and reinforced concrete", BIS Publication, New Delhi

[5]. IS: 1905-1987 "Code of practice for structural use of un-reinforced masonry", BIS Publication, New Delhi

[6]. IS: 2185(Part I)-1979 "Specification for concrete masonry units", BIS Publication, New Delhi

[7]. IS: 2250-1981 "Code of practice for Masonry mortars", BIS Publication, New Delhi

[8]. BibianaLuccioni ${ }^{1}$ and Viviana C. Rougier ${ }^{2}$ (2010), "In-plane retrofitting of masonry panels with fibre reinforced composite materials", 'Structures Institute, National University of Tucumán, Argentina, National Technological University, Uruguay.

[9]. Claudio Modena (2001), "Reinforced and Rectified Clay blocks masonry", University of Padua, Padua, Italy

[10]. Raghunath s. (2003) "Static and Dynamic behavior of Brick Masonry with Containment Reinforcement", $\mathrm{PhD}$ Thesis submitted to Dept of Civil Engineering, IISC, Bangalore

[11]. Dhanasekar M (2003), "Effect of Grout Comfinement on the Compressive Strength of masonry", Journal of Institute of engineers, New Delhi.

[12]. Hemanth Kumar.M.N, “ Flexural and Shear Strength of Hollow Concrete Block Masonry Prisms under Normal Stress", M.Tech Thesis submitted to Dept of Civil Engineering, BMS College of Engineering, V.T.U Belgaum

[13]. M.Corradi ${ }^{1}$, C. Tedeschi ${ }^{2}$, L. Binda ${ }^{2}$, A. Borri ${ }^{1}$ (2007), "Experimental evaluation of shear and compression strength of masonry wall before and after reinforcement: Deep repointing", ${ }^{1}$ Department of Civil and Environmental Engineering, University of Perugia, Italy , ${ }^{2}$ DIS-Dept. of Structural Engineering, Politecnico of Milan, Italy, Available online Science Direct

[14]. Matthias Ernst ${ }^{1}$, Gert König ${ }^{2}$, "Shear Strength and Compressive Strength of Reinforced perforated clay block masonry", 1 Institute für Massivbau, TH Darmstadt, now Ingenieurbüro BUNG , ${ }^{2}$ Institute für Massivbau und Baustofftechnologie i. Gr., Universität Leipzig

[15]. Manih.S, "Experimental and Analytical Studies on Reinfoced Masonry", M.Tech Thesis submitted to Dept of Civil Engineering, BMS College of Engineering, V.T.U Belgaum

[16]. Petras Pukelis, "Estimation in LST EN 1996-1-1 of Influence of Transversal bed joint reinforcement on Compressive Strength of Masonry", Dept of Reinforced Concrete and Masonry Structures, Vilnius Gediminas Technical University, Sauletekio al.

[17]. Oliviera (2008), "Axial compression behavior of concrete masonry wallettes strengthened with cement mortar overlays", Ibracon structures and material journal, Volume 1, p.158-170 